
journal by the Ministry of Research-Technology and Higher Education Republic of Indonesia: No. 28/E/KPT/2019 [SINTA-5]

\title{
Perlindungan Hukum bagi Konsumen terhadap Pengembalian Uang Sisa Belanja dalam Bentuk Barang/Permen di Kecamatan Kedungwaru Kabupaten Tulungagung
}

\author{
Legal Consumer Protection Against Refund of Remaining Expenditure in the Forms of \\ Goods: The Case of Kedungwaru District, Tulungagung
}

\section{Hariyanti, ${ }^{\bowtie}$ Djulaeka}

Fakultas Hukum Universitas Trunojoyo Madura, Jawa Timur, Indonesia

DOI: $10.32781 /$ cakrawala.v15i1.371

\begin{tabular}{l} 
ARTICLE INFO \\
Konsumen, \\
Perlindungan Hukum, \\
Uang Kembalian. \\
\hline Article History: \\
Received : 17 April 2021 \\
Accepted : 16 Juni 2021 \\
Publish : 17 Juni 2021
\end{tabular}

\begin{abstract}
Abstrak:
Praktik pemberian uang kembalian sisa belanja dengan barang dagangan (baca: permen) kerap terjadi pada konsumen yang berakibat pada tidak terpenuhinya hakhak konsumen. Pelaku usaha beralasan bahwa pemberian uang sisa belanja dengan barang dagangan dilakukan karena tidak tersedianya nominal uang kecil. Penelitian ini merupakan penelitian empiris yang mengkaji implementasi Peraturan Daerah Kabupaten Tulungagung Nomor 1 Tahun 2018 tentang Penataan dan Pembinaan Pasar Rakyat, Pusat Perbelanjaan dan Toko Swalayan di Wilayah Kecamatan Kedungwaru, Kabupaten Tulungagung. Melalui pendekatan faktadengan melakukan wawancara secara langsung di lapangan, serta telaah bahan hukum sebagai data sekunder, kemudian dianalisis dan didiskripsikan menjadi jawaban atasisu hukum dalam penelitian ini. Hasil penelitian menunjukkan bahwa pemberian uang sisa belanja dalam bentuk barang dagangan di Kecamatan Kedungwaru, Kabupaten Tulungagung telah melanggar hak-hak konsumen, sesuai dengan ketentuan Undang-Undang Perlindungan Konsumen Pasal 4 dan 15 dan Pasal 42 huruf (g), Peraturan Daerah Kabupaten Tulungagung Nomor 1 Tahun 2018 tentang Penataan dan Pembinaan Pasar Rakyat, Pusat Perbelanjaan dan Toko Swalayan dan Pasal 2 Undang-Undang Nomor 23 Tahun 1999 tentang Bank Indonesia, serta Pasal 21 Undang-Undang Nomor 7 Tahun 2011 tentang Mata Uang dan dibutuhkan adanya ketegasan sanksi bagi pelaku usaha yang masih melakukan pelanggaran terhadap peraturan terkait.
\end{abstract}

\section{Abstract:}

The practice of giving change for the rest of the shopping with merchandise (read: candy) often occurs to consumers which results in not fulfilling consumer rights. The business actor argued that the remaining money for spending in merchandise was made because of the unavailability of a small amount of money. This research is an empirical study that examines the implementation of the Regional Regulation of Tulungagung Regency Number 1 of 2018 concerning Structuring and Development of People's Markets, Shopping Centers and Supermarkets in Kedungwaru District, Tulungagung Regency. Through the fact approach by conducting interviews directly in the field, as well as reviewing legal materials as secondary data, then analyzed and described as answers to legal issues in this study. The results showed that the provision of leftover spending money in the form of merchandise in Kedungwaru District, Tulungagung Regency has violated consumer rights, in accordance with the provisions of Article 4 and 15 Consumer Protection Act and Article 42 (g), Tulungagung Regency Regional Regulation Number 1 of 2018 concerning Structuring and Development of People's Markets, Shopping Centers and Supermarkets and Article 2 of Law Number 23 of 1999 concerning Bank Indonesia, as well as Article 21 of Law Number 7 of 2011 concerning Currency and there are need for strict sanctions for business actors who are still violating the relevant regulations. 


\section{PENDAHULUAN}

Perkembangan zaman yang semakin modern, menyebabkan adanya perkembangan yang pesat terhadap pasar modern dan toko swalayan yang mempermudah masyarakat dalam melakukan kegiatan transaksi jual beli. Dengan adanya keadaan ini, menjadikan pelaku usaha melakukan penawaran berupa potongan harga, agar terlihat lebih murah dibandingkan dengan toko lain. Potongan harga yang nominalnya tidak bulat ini, menjadi kendala tersendiri pada saat pengembalian uang sisa belanja. Pelayan toko biasanya tidak ambil pusing dengan tidak tersedianya uang dengan nominal kecil, mereka biasanya memberikan pengembalian dengan barang yakni bisa permen atau jenis makanan ringan lainnya yang dianggap mampu menggantikan nilai uang sisa belanja tersebut. Kadang konsumen juga mengeluh dengan tindakan pelaku usaha tersebut, selain karena nilai permen atau jenis makanan ringan tidak memenuhi nilai uang kembalian, barang dagangan yang dijadikan kembalian belum tentu pilihan dari konsumen, sehingga konsumen seakan-akan tidak diberikan pilihan oleh pelaku usaha. Padahal konsumen mempunyai hak untuk memilih (the right to choose) sesuai slogan konsumen adalah raja, sehingga tidak ada suatu alas an untuk memaksa konsumen melakukan pilihan tertentu yang merugikan dirinya, seperti dalam penawaran yang condong untuk menentukan pilihan menerima pengembalian sisa uang belanja dengan barang atau permen sebagai pengganti.

Fenomena pengembalian uang belanja dengan permen atau barang sejenis lainnya telah menjadi tren yang cukup lama dikeluhkan oleh konsumen. Di Gorontalo keluhan konsumen terkait hal tersebut sudah mulai muncul semenjak Tahun 2015. (Hukumonline.com, 2015) Pengembalian menggunakan permen juga masih terjadi di Jawa Tengah tahun 2018. (Kompasiana.com, 2018) Keluhan serupa juga melanda konsumen yang berada di wilayah Kepulauan Bangka dan Kepulauan Riau, Kabupaten Rokan Hulu, sehingga dikeluarkan adanya Surat Edaran Disperindag setempat terkait larangan pelaku usaha untuk pengembalian belanja dengan permen. Konsumen di Kota Mbay Kabupaten Nagekeo, Flores mmengeluhkan hal yang sama (Larantuka.com/2019) Di Salatiga, hal serupa masih terjadi (Rahmawati, 2020). Meskipun konsumen berhak menolak, namun jarang sekali dilakukan oleh konsumen. Bahkan larangan untuk transaksi yang menggunakan selain rupiah dilarang oleh UU Bank Indonesia, bahwa alat pembayaran yang sah adalah rupiah. Tidak tersedianya uang receh menjadi alasan klasik pelaku usaha untuk melakukan penggantian dengan permen, alasan ini tidak dapat dijadikan alasan pembenar karena BI sudah menyediakan uang logam pecahan kecil untuk kembalian.

Masyarakat luas pada umumnya tidak pernah lepas dari segala aktivitas antara satu masyarakat dengan masyarakat lainnya, salah satu hubungan timbal balik antara sesama masyarakat adalah kegiatan jual beli. Dalam hal jual beli, terdapat dua orang atau lebih yang biasanya sering disebut dengan konsumen dan pelaku usaha. Konsumen merupakan orang yang memakai barang dan jasa. Sedangkan pelaku usaha merupakan setiap orang atau badan usaha yang melakukan kegiatan usaha di wilayah hukum Republik Indonesia. Dalam kegiatan jual beli antara pembeli dan penjual bisa diibaratkan sebuah perjanjian yang mana keduanya harus sepakat dan memiliki itikad baik. Dalam melakukan perjanjian syarat sah terbentuknya perjanjian yang harus dipenuhi adalah adanya kesepakatan kedua belah pihak, kecakapan untuk melakukan perjanjian, suatu hal tertentu dan suatu sebab yang halal. 
Pemberian uang sisa belanja dengan barang/permen masih sering terjadi di Kecamatan Kedungwaru, Kabupaten Tulungagung. Banyaknya toko swalayan yang berkembang di Kabupaten ini, sehingga tidak menjamin sepenuhnya akan hak konsumen, khusunya dalam hal pengembalianuang sisabelanjasesuaiaturan yang ada. Dengan adanya tindakan pelaku usaha yang melakukan pengembalian uang sisa belanja dengan barang dagangan, maka diperlukan kajian lebih dalam mengenai fenomena pengembalian uang sisa belanja dengan barang dagangan di Kecamatan Kedungwaru, Kabupaten Tulungagung di tinjau dalam UUPK dan Peraturan Daerah Kabupaten Tulungagung Nomor 1 Tahun 2018. Berkenaan dengan hal ini, maka artikel ini mengkaji terkait Pertama, Apakah tindakan pelaku usaha yang melakukan pengembalian uang sisa belanja dengan barang di Kecamatan Kedungwaru, Kabupaten Tulungagung melanggar hak-hak konsumen? Kedua, Bagaimana pelaksanaan sanksi yang dilakukan oleh pemerintah daerah Kabupaten Tulungagung terkait adanya pelanggaran terhadap Pasal 42 huruf (g) Peraturan Daerah Kabupaten Tulungagung Nomor 1 Tahun 2018 di Kecamatan Kedungwaru, Kabupaten Tulungagung?

\section{TINJAUAN PUSTAKA}

Penelitian yang dilakukan Syahputra \& Hambali (2019), menunjukkan bahwa bahwa konsumen tidak puas ketika dilakukan sisa pengembalian berupa barang/ permen dan sebaliknya terjadi peningkatan kepuasan jika pengembalian uang saat transaksi jual beli tidak berupa permen atau sejenisnya, sehingga berpengaruh pula terhadap peningkatan omzet penjualan" (Syahputra \& Hambali, 2019). Isyarat untuk melakukan manajemen pencatatan dalam sebuah sistem elektronik sesuai jumlah pengembalian konsumen yang diperhitungkan sebagai saving pada pelaku usaha, merupakan solusi yang menarik yang ditawarkan dalam penelitian (Swari, 2016).

Undang-Undang Republik Indonesia Nomor 8 Tahun 1999 tentang Perlindungan Konsumen (selanjutnya disebut UUPK) mengatur mengenai hak-hak konsumen, yang disebutkan dalam Pasal 4. Praktik pemberian uang sisa belanja dengan barang telah melanggar ketentuan Pasal 4 huruf (b) UUPK, yang mana adanya pemberian uang sisa belanja dengan barang dagangan menjadikan konsumen mendapatkan barang yang tidak sesuai dengan nilai tukar. Bila dilihat dengan Undang-Undang lain, pemberian pengembalian uang sisa belanja dengan barang telah melanggar ketentuan Undang-Undang Nomor 23 Tahun 1999 tentang Bank Indonesia (Selanjutnya disebut UU BI) yang menyebutkan:"Setiap perbuatan yang menggunakan uang atau mempunyai tujuan pembayaran atau kewajiban lain yang harus dipenuhi dengan uang jika dilakukan di wilayah Republik Indonesia wajib menggunakan uang rupiah"Sedangkan ketentuan UndangUndang Nomor 7 Tahun 2011 tentang Mata Uang (selanjutnya disebut UU Mata Uang) menyebutkan:"Rupiah wajib digunakan dalam:

- Setiap transaksi yang mempuyai tujuan pembayaran

- Penyelesaian kewajiban lainnya yang harus dipenuhi dengan uang; dan/atau

- Transaksi keuangan lainnya yang dilakukan di wilayah negara kesatuan Republik Indonesia"

Di Kabupaten Tulungagung sebenarnya telah dibentuk Peraturan Daerah Kabupaten Tulungagung Nomor 1 Tahun 2018 tentang Penataan dan Pembinaan Pasar Rakyat, Pusat Perbelanjaan dan Toko Swalayan (Selanjutnya disebut Peraturan Daerah Kabupaten Tulungagung Nomor 1 Tahun 2018), dalam Pasal 42 menyebutkan bahwa: 
"Setiap pengelola pasar rakyat, pusat perbelanjaan dan toko swalayan dilarang:

a. Melakukan penguasaan atas produksi dan/atau barang dan jasa secara monopoli

b. Melakukan praktik persaingan usaha tidak sehat

c. Menimbun dan menyimpan bahan kebutuhan pokok masyarakat di dalam gudang dalam jumlah melebihi kewajaran untuk tujuan spekulasi yang akan merugikan masyarakat

d. Menimbun dan/atau menyimpan barang-barang yang sifat dan jenisnya membahayakan kesehatan

e. Menjual barang-barang yang telah kadaluarsa

f. Mengubah dan menambah sarana tempat usaha, jenis dagangan dan merubah peruntukkannya tanpa ijin dari Bupati

g. Mengganti uang pengembalian pada setiap transaksi dengan barang dagangan

h. Memakai tenaga kerja dibawah umur dan/atau tenaga asing tanpa ijin berdasarkan ketentuan peraturan perundang-undangan yang berlaku."

Ketentuan pada Pasal 42 huruf (g) Peraturan Daerah Kabupaten Tulungagung Nomor 1 Tahun 2018, menyebutkan bahwa "setiap pengelola pasar, pusat perbelanjaan dan toko swalayan dilarang untuk mengganti uang pengembalian pada setiap transaksi dengan barang dagangan". Dengan adanya peraturan ini, seharusnya pelaku usaha tidak melakukan tindakan pengembalian uang sisa belanja dengan barang dagangan. Akan tetapi, setelah dilakukan pengamatan sederhana, banyak pelaku usaha yang mengabaikan ketentuan ini, selain itu kurangnya pengetahuan tentang perlindungan hak-hak konsumen dalam peraturan daerah ini, menjadikan masyarakat membiarkan hal ini terjadi dan akhirnya mengikuti kehendak dari pelaku usaha tersebut. Padahal pelanggaran terhadap ketentuan peraturan daerah tersebut dapat dikenakan sanksi, baik lisan sampai dengan pencabutan tetap izin usaha.

\section{METODE PENELITIAN}

Penelitian ini merupakan penelitian hukum empiris yang merupakan penelitian hukum yang menganalisis dan mengkaji bekerjanya hukum di masyarakat, dilihat dari efektivitas hukum, kepatuhan hukum, peranan lembaga hukum atau institusi hukum di dalam penegakan hokum (HS \& Nurbani, 2014). Penelitian ini menggunakan pendekatan fakta, yaitu penelitian dengan mengangkat suatu fakta yang ada agar diketahui fakta dan hukumnya (Zainudin, 2016). Lokasi yang menjadi tempat penelitian adalah di Kecamatan Kedungwaru, Kabupaten Tulungagung. Pemilihan lokasi ini dikarenakan Kec. Kedungwaru merupakan salah satu kecamatan di Kabupaten Tulungagung, sehingga kecamatan ini juga menjadi sasaran implementasi Peraturan Daerah Kabupaten Tulungagung Nomor 1 Tahun 2018. Sumber data dalam penelitian ini meliputi sumber data primer (diperoleh langsung dengan wawancara, observasi) dan sumber data sekunder yang diperoleh dari bahan hukum primer (Undang-Undang, Peraturan Daerah) dan bahan hukum sekunder (buku, jurnal, hasil penelitian lain yang berhubungan). Teknik pengumpulan data dalam penelitian ini ada tiga, yaitu:

a. Wawancara, yakni tanya jawab secara langsung kepada responden atau narasumber.

b. Observasi, yakni kegiatan pengamatan langsung terhadap objek yang diteliti

c. Kuesioner, yakni pertanyaan tertulis yang disusun secara sistematis yang mempunyai tujuan untuk mendapatkan tanggapan atau respon dari beberapa orang dalam penelitian. 
HASIL DAN PEMBAHASAN

Tindakan Pelaku Usaha dalam Melakukan Pengembalian Uang Sisa Belanja dengan Barang di Kecamatan Kedungwaru, Kabupaten Tulungagung

Kecamatan Kedungwaru merupakan salah satu kecamatan yang terdapat di Kabupaten Tulungagung. Kecamatan ini memiliki 19 (Sembilan belas) desa yaitu Desa Bangoan, Boro, Bulusari, Gendingan, Kedungwaru, Ketanon, Loderesan, Majan, Mangunsari, Ngujang, Plandaan, Ploso kandang, Rejoagung, Ringin pitu, Simo, Tapan, Tawangsari, Tunggulsari dan Winong, serta mempunyai 127 Rukun Warga (RW) dan 480 Rukun Tetangga (RT). (Badan Pusat Statistik Kabupaten Tulungagung, 2017) di sektor perdagangan, di Kecamatan Kedungwaru terdapat 5 (lima) pasar tradisional yang terletak di desa Bangoan, Plosokandang, Kedungwaru, Simo, dan Ngujang. Sedangkan jumlah toko swalayan (meliputi indomaret, alfamart, toko) berjumlah 161, dan toko pracangan sebanyak 829 toko yang tersebar di wilayah desa-desa di Kecamatan Kedungwaru. Seperti kegiatan jual beli pada umumnya, pelaksanaan transaksi jual beli di Kecamatan Kedungwaru, Kabupaten Tulungagung dilakukan dengan adanya kesepakatan antara pembeli (konsumen) dan penjual (pelaku usaha).

Konsumenmerupakan pemakaibarang dan jasa (Celina, 2016). Yang dimaksud konsumen dalam penelitian ini merupakan konsumen akhir, yakni pemakai barang atau jasa, untuk keperluan sendiri, keluarga atau orang lain dan tidak untuk diperdagangkan kembali (Simangunsong \& Sari, 2005). Sedangkan pelaku usaha, dalam Black's Law Dictionary, dikenal dengan istilah producer, yang memiliki arti yang orang yang menghasilkan (Kurniawan, 2011). Dalam UU PK pengertian pelaku usaha juga mempunyai makna yang luas, yang mana dalam UU PK, pelaku usaha yang termasuk cakupannya bisa perusahaan, BUMN, koperasi, importir, pedagang, distributor, dan lainnya. Yang menarik dalam kegiatan jual beli di Kecamatan Kedungwaru, Kabupaten Tulungagung adalah ketika konsumen melakukan pembayaran, dan masih ada uang sisa kembalian, maka tidak jarang pelaku usaha memberikan barang dagangan lainnya, yang dianggap mampu menggantikan nominal uang sisa tersebut. Dalam kondisi seperti ini, pelaku usaha tidak boleh mengabaikan pentingnya kesepakatan dengan konsumen sebelumnya (Ariestya et al., 2015). Hal ini dibutuhkan adanya keseimbangan antara hak dan kewajiban dalam transaksi yang dilakukan antara konsumen dan pelaku usaha, sebagaimana konsumen diwajibkan untuk membayar sesuai dengan nilai tukar yang disepakati; Pasal 5 ayat (3) UUPK.

Dari 30 (tiga puluh) responden konsumen akhir yang berada di Kecamatan Kedungwaru, Kabupaten Tulungagung, mengatakan pernah menerima kembalian uang sisa belanja dengan barang dagangan. Sebagian besar dari mereka sering menerima permen atau jenis makanan ringan sebagai pengganti uang sisa belanja. Selain karena terpaksa menerima kembalian dengan barang dagangan yang diberikan oleh pelaku usaha, tidak adanya pengetahuan yang cukup tentang hak-haknya sebagai konsumen dan peraturan yang mengatur mengenai pelarangan pemberian uang sisa belanja dengan barang ini menjadikan konsumen merasa dan menjadikan ini hal yang biasa, walaupun pada dasarnya mereka keberatan karena mendapatkan barang yang seharusnya tidak ia beli.

Sedangkan dari 20 (dua puluh) pelaku usaha di Kecamatan Kedungwaru, Kabupaten Tulungagung yang telah diwawancarai dan mengisi kuesioner menyatakan pernah melakukan pemberian uang sisa belanja dengan barang terhadap konsumen. Ketidaktahuan pada UU PK dan Pasal 42 huruf (g) Peraturan Daerah Kabupaten Tulungagung Nomor 1 Tahun 
2018 menjadikan pelaku usaha melakukan tindakan ini terus menerus. Sebagian besar pelaku usaha tersebut mempunyai alasan yang sama terkait tindakan mereka melakukan pengembalian uang sisa belanja dengan barang dagangan yakni tidak tersedianya uang dengan nominal kecil. Tidak adanya nominal uang kecil ini seakan-akan telah menjadikan pelaku usaha merasa bahwa pemberian uang kembalian sisa belanja dengan barang dagangan merupakan jalan terakhir untuk pemenuhan hak uang kembalian konsumen tersebut, padahal apabila pelaku usaha tidak mempunyai uang dengan nominal kecil sebagai kembalian uang sisa belanja, maka pelaku usaha dapat melakukan penukaran uang melalui bank.

Dalam UU Pasal 22 Undang-Undang Republik Indonesia Nomor 7 Tahun 2011 tentang Mata Uang (selanjutnya disebut UU Mata Uang), menyebutkan mengenai pengaturan perihal penukaran uang rupiah, yakni:

1. Untuk memenuhi kebutuhan rupiah di masyarakat dalam jumlah nominal yang cukup, jenis pecahan yang sesuai, dan dalam kondisi yang layak edar, rupiah yang beredar di masyarakat dapat ditukarkan dengan ketentuan sebagai berikut:

a. Penukaran rupiah dapat dilakukan dalam pecahan yang sama atau pecahan yang lain dan/atau,

b. Penukaran rupiah yang lusuh dan/ atau rusak sebagian karena terbakar atau karena sebab lainnya dilakukan penggantian dengan nilai yang sama nominalnya.

2. Penukaran rupiah yang rusak sebagian karena terbakar atau sebab lain sebagaimana dimaksud dalam ayat 1 huruf (b) dilakukan penggantian apabila tanda keaslian rupiah tersebut masih dapat diketahui atau dikenali

3. Kriteria rupiah yang lusuh dan/atau rusak yang dapat diberikan penggantian sebagaimana dimaksud pada ayat 1 huruf (b) dan ayat (2) doatur dengan ketentuan Bank Indonesia

4. Penukaran rupiah sebagaimana dimaksud pada ayat (1) dilakukan oleh Bank Indonesia, bank yang beroperasi di Iindonesia, atau pihak lain yang ditunjuk oleh Bank Indonesia

Adanya pengaturan mengenai penukaran uang tersebut, menegaskan bahwa sebenarnya penukaran uang rupiah dengan nominal lain dapat dilakukan, sehinggamempermudah masyarakat luas untuk mendapatkan uang dengan nominal yang diinginkan. Sehingga bukan menjadi alasan lagi bagi pelaku usaha untuk mengatakan bahwa ada kendala dalam hal penukaran uang dengan nominal uang yang lebih kecil.

Apabila dikaji lebih lanjut, tindakan pemberian uang sisa belanja yang dilakukan oleh pelaku usaha yang bertentangan dengan ketentuan hukum yang berlaku, dapat dikenakan sanksi pidana bagi pelaku usaha itu sendiri. Seperti yang disebutkan dalam UU Mata Uang Pasal 33, bahwa:

1. Setiap orang yang tidak menggunakan rupiah dalam:

a. Setiap transaksi yang mempunyai tujuan pembayaran

b. Penyelesaian kewajiban lainnya yang harus dipenuhi dengan uang dan/atau

c. Transaksi keuangan lainnya sebagaimana dimaksud dalam Pasal 21 ayat (1) dipidana dengan pidana kurungan paling lama 1 (satu) tahun dan pidana denda paling banyak Rp 200.000.000,00 (dua ratus juta rupiah).

2. Setiap orang dilarang menolak untuk menerima rupiah yang penyerahannya dimaksudkan sebagai pembayaran atau untuk menyelesaikan kewajiban yang harus dipenuhi dengan rupiah dan/ atau untuk transaksi keuangan lainnya di wilayah Negara Republik Indonesia 
kecuali karena terdapat keraguan atas keaslian rupiah sebagaimana dimaksud dalam Pasal 23 dipidana dengan pidana kurungan paling lama 1 (satu) tahun dan denda paling banyak $\mathrm{Rp}$ 200.000.000,00 (dua ratus juta rupiah).

Dengan demikian, maka adanya praktik pemberian uang sisa belanja dengan barang/permen yang masih dilakukan di wilayah Kecamatan Kedungwaru, KabupatenTulungagung dapat dikatakan telah mengabaikan adanya prinsip keseimbangan dalam transaksi sehingga melanggar hak-hak konsumen sebagaimana yangdiatur dalam UU PK, UU Mata Uang maupun Peraturan Daerah Kabupaten Tulungagung Nomor 1 Tahun 2018. Tentunya konsumen harus menggunakan hak jawab ataupun melakukan penolakan atas tindakan sepihak pelaku usaha yang memaksa menerima pengembalian selain rupiah.

\section{Pelaksanaan Sanksi Terkait Tindakan Pelaku Usaha yang Melakukan Pengembalian Uang Sisa Belanja dengan Barang di Kecamatan Kedungwaru Kabupaten Tulungagung}

Rahardjo (2000), dalam bukunya mengatakan, bahwa perlindungan hukum merupakan upaya untuk mengorganisasikan berbagai kepentingan dalam masyarakat agar tidak terjadi benturan antar kepentingan dan agar dapat menikmati semua hak yang diberikan oleh hukum. Hal ini mencerminkan adanya prinsip perlindungan hukum harus selalu melekat pada masyarakat. Negara mempunyai kewajiban dalam memberikan kenyamanan dalam kehidupan di masyarakat. Dalam perspektif kajian teori gangguan umum (general nuisance theory) jelas dalam memberikan kedudukan negarauntuk melarang gangguan public (Darrow, 1966).

Pengembalian uang sisa belanja dengan barang memang tidak diatur secara jelas dalam UU PK, akan tetapi dalam Pasal 4 dan Pasal 77 UU PK masing-masing mengatur mengenai hakhak konsumen dan kewajiban pelaku usaha, sehingga yang menjadi landasan dalam hal ini adalah adanya pengaturan mengenai perlindungan hak-hak konsumen dan kewajiban pelaku usaha (Adelia, 2018). Perlindungan konsumen tentunya memberikan kebebasan bagi konsumen dalam menentukan pilihannya secara rasional (Huffman, 2010).

Dalam Pasal 4 huruf (b) dijelaskan bahwa konsumen mempunyai hakuntuk memilih barang dan jasa sesuai dengan nilai tukar dan kondisi serta jaminan yang dijanjikan, dengan adanya ketentuan ini seharusnya konsumen mendapatkan barang yang dibeli dari pelaku usaha sesuai dengan kesepakatan awal. Adanya pengembalian uang sisa belanja dengan barang, menjadikan konsumen menerima pengembalian dengan barang tersebut, meskipun dalam kesepakatan adanya pengembalian dengan barang tidak dibicarakan, tidak disepakati sebelumnya oleh konsumen dan pelaku usaha.

Disisi lain, dalam Pasal 7 UU PK, pelaku usaha dalam melakukan kegiatan usahanya mempunyai kewajiban yang diantaranya adalah beritikad baik dalam melayani dan memperlakukan konsumen secara benar dan jujur serta tidak melakukan tindakan diskriminatif, sehingga perlu pelaku usaha memberikan pilihan terkait pengembalian uang sisa belanja dengan barang, agar konsumen dapat memilih beberapa opsi pengembalian uang sisa belanja tersebut.

Selain itu, Pasal 15 UUPK disebutkan bahwa "Dalam melakukan tindakan jual beli, pelaku usaha dalam melakukan penawaran barang dan jasa pelaku usaha dalam melakukan penawaran barang atau jasa dilarang melakukan dengan cara pemaksaan atau cara lain yang dapat menimbulkan gangguan baik fisik maupun psikis terhadap konsumen".Ketentuan 
dalam Pasal ini lebih tertuju pada "perilaku" dan "cara-cara penjualan" yang dilakukan oleh pelaku usaha dalam kegiatan jual beli yang dilakukannya, dalam Pasal 15 ini cara pemaksaan yang dimaksud adalah cara paksaan yang menjadikan posisi konsumen dalam keadaan yang lemah (Miru \& Yodo, 2010).

Dalam hal ini pelaku usaha seakanakan melakukan pemaksaan pembelian barang (yang dijadikan pengembalian), yang pada dasarnya konsumen tidak berniat untuk membeli barang tersebut. Akan tetapi dengan dalih tidak adanya uang nominal kecil menjadikan konsumen terpaksa menerima pengembalian uang sisa belanja dengan barang, hal ini menunjukkan perbuatan yang menyesatkan atau mengelabuhi konsumen dan yang pasti merugikan konsumen. Pelanggaran terhadap Pasal 15 UUPK ini dapat dikenai sanksi pidana penjara paling lama 5 (lima) tahun dan pidana denda. Sedangkan pelanggaran terhadap Pasal 42 huruf (g) Peraturan Daerah Kabupaten Tulungagung Nomor 1 Tahun 2018 terkait pengembalian uang sisa belanja dengan barang dikenai sanksimulai dari teguran lisan sampai dengan pencabutan tetap izin usaha.

Proses pembinaan dan pengawasan dalam hal ini dilimpahkan kepada Dinas Perindustrian dan Perdagangan, hal ini sesuai dengan yang tercantum pada Pasal 43 Peraturan Daerah Kabupaten Tulungagung Nomor 1 Tahun 2018. Selain itu, pengawasan juga dilakukan oleh Bagian Hukum Setda Kabupaten Tulungagung dan Satpol PP terkait implementasi Peraturan Daerahnyaterhadap adanya pelanggaran hak-hak konsumen dalam pemberian uang sisa belanja dengan barang/permen di Kecamatan Kedungwaru, Kabupaten Tulungagung.

Selama diberlakukannya Peraturan Daerah ini, belum ada laporan dari konsumen akhir di Kecamatan Kedungwaru, Kabupaten Tulungagung kaitannya dengan pemberian uang sisa belanja dengan barang yang dilakukan oleh pelaku usaha. Tidak adanya laporan mengenai pelanggaran terhadap hak-hak konsumen ini, dilatarbelakangi karena tidak adanya pengetahuan masyarakat terhadap hak-haknya sebagai konsumen sesuai UU PK maupun Peraturan Daerah Kabupaten Tulungagung Nomor 1 Tahun 2018. Bekerjanya hukum dalam masyarakat dapat dikatakan efektif, apabila masyarakat mentaati dan melaksanakan dengan baik sesuai norma yang ada (Novita \& Santoso, 2021).

Padahal apabila konsumen mengalami keberatan atau merasa dirugikan atas pelanggaran hak-haknya tersebut, maka konsumen dapat melakukan pelaporan terhadap dinas terkait, sehingga pelaku usaha yang melakukan pelanggaran terhadap hak-hak konsumen kaitannya dengan pemberian pengembalian uang sisa belanja dengan barang ini dapat ditindak lebih lanjut, sehingga penerapan sanksi administratif dapat diterapkan terhadap pelaku usaha yang melakukan pelanggaran terhadap hak konsumen.

Dari hasil penelitian, mengindikasikan bahwa Pemerintah Daerah Tuluanggung sudah memberikan pelayanan dan pengayoman terbaik bagi masyarakat secara keseluruhan dengan terbitnya Peraturan Daerah yang mengatur tentang Penataan dan Pembinaan Pasar Rakyat, Pusat Perbelanjaan dan Toko Swalayan, meskipun dalam praktiknya masyarakat Tulungagung tidak menggunakan hak gugat pada pelaku usaha, baik disebabkan ketidakpahaman masyarakat akan Peraturan Daerah dimaksud atau sosialisasi masih belum dapat dilaksanakan secara maksimal.

\section{SIMPULAN}

Dari hasil penelitian ini dapat disimpulkan yakni sebagai berikut, 1) Prinsip keseimbangan antara hak dan kewajiban 
konsumen maupun pelaku usaha harus dilakukan sebagaimana dalam UUPK. Jika tindakan pelaku usaha memberikan kembalian uang sisa belanja dengan barang/permen dapat dikatakan telah melakukan pelanggaran hak konsumen dan memberikan hak bagi konsumen untuk menggunakan hak jawab dengan melakukan penolakan ataupun tidak menerima tindakan sepihak pelaku usaha yang memaksa memberikan pengembalian berupa barang/permen. 2) Pelanggaran Pasal 42 huruf (g) Peraturan Daerah Penataan dan Pembinaan Pasar Rakyat, Pusat Perbelanjaan dan Toko Swalayan. yang dilakukan pelaku usaha, sebatas pada sanksi teguran secara lisan sampai pada pencabutan ijin usaha. Dibutuhkan adanya ketegasan dari aparat terkait dalam penerapan sanksi administratif sesuai dengan peraturan yang berlaku, agar pelaku usaha yang melakukan pelanggaran jera atas tindakannya yang melanggar hak dan kepentingan konsumen. Rekomendasi dari hasil penelitian ini adalah peran serta pemerintah (pusat/daerah), lembaga perlindungan konsumen, asosiasi pelaku usaha, kelompok konsumen serta tersedianya peraturan yang mendukung perlindungan bagi konsumen, akan memberikan keberhasilan perlindungan konsumen yang memadai. Dan dibutuhkan adanya itikad baik dalam setiap transaksi konsumen - pelaku usaha untuk menjaga kenyamanan konsumen dan kepercayaan pelaku usaha dalam suatu transaksi jual beli.

\section{DAFTAR PUSTAKA}

Adelia, T. (2018). Kajian Hukum Terhadap Pengembalian Uang Koin dalam Bentuk Permen Kepada Pelanggan yang Dilakukan oleh Pengusaha Menurut UndangUndang Nomor 8 Tahun 1999 tentang Perlindungan Konsumen dan Undang-Undang Nomor 7 Tahun 2011 Tentang Mata Uang [Universitas Sumatera Utara]. https://doi.org/http://repositori. usu.ac.id/handle/123456789/4202

Ariestya, F., Bachtiar, M., \& Fitriani, R. (2015). Perlindungan Hukum terhadap Konsumen yang Menerima Alat Pembayaran yang Tidak Sah dalam Transaksi Jual Beli Ditinjau dari Undang-Undang Nomor 8 Tahun 1999 Tentang Perlindungan Konsumen. Jurnal Online Mahasiswa Fakultas Hukum Universitas Riau, 2(2).

Badan Pusat Statistik Kabupaten Tulungagung. (2017). Kecamatan Kedungwaru Dalam Angka 2017. http://tulungagungkab.bps.go.id/ publication.html

Celina Tri Siwi, K. (2016). Hukum Perlindungan Konsumen.

Darrow, P. H. (1966). Commercial Nuisance: A Theory of Consumer Protection. The University of Chicago Law Review, 33(3). 
HS, S., \& Nurbani, E. S. (2014). Salim HS dan Erlies Septiana Nurbani. PT Raja Grafindo.

Huffman, M. (2010). Bridging The Divide? Theories For Integrating Competition Law And Consumer Protection. European Competition Journal, 11.

Kurniawan. (2011). Hukum Perlindungan Konsumen (Problematika Kedudukan dan Kekuatan Putusan Badan Penyelesaian Sengketa Konsumen). Universitas Brawijaya Press (UB Press).

Miru, A., \& Yodo, S. (2010). Hukum Perlindungan Konsumen. Rajawali Pers.

Nagekeo : Konsumen Resah Pengembalian Uang Dengan Permen. (2019). https://larantuka.com/

Novita, Y. D., \& Santoso, B. (2021). Urgensi Pembaharuan Regulasi Perlindungan Konsumen di Era Bisnis Digital. Jurnal Pembangunan Hukum Indonesia, 3(1), 46-58. https://doi.org/https:// doi.org/10.14710/jphi.v3i1.46-58

Rahardjo, S. (2000). Ilmu Hukum. PT. Citra Aditya Bakti.

Rahmawati, L. (2020). Praktik Pengalihan Uang Sisa Belanja Dengan Permen Ditinjau Dari Hukum Islam Dan Undang Undang No 8 Tahun 1999 Tentang Perlindungan Konsumen (Studi Kasus Swalayan Bc Mart 1 Salatiga) [Institut Agama Islam Negeri (IAIN) Salatiga]. http://erepository.perpus.iainsalatiga. ac.id/id/eprint/8766
Simangunsong, A., \& Sari, E. K. (2005). Hukum Dalam Ekonomi. PT Grasindo Anggota IKAPI.

Swari, M. H. P. W. (2016). Rancang Bangun Sistem Elektronik Manajemen Pengembalian Uang Pelanggan Pada Retail Teritegrasi.Jurnal S@ CIES, 7(1), 15-23. https://doi.org/ https://doi.org/10.31598/sacies. v7i1.110

Syahputra, G., \& Hambali, H. (2019). Dampak Transaksi Jual Beli Dengan Pengembalian Menggunakan Permen Terhadap Omzet Penjualan. Jurnal Kinerja, 2, 147-151. https://doi.org/ http://dx.doi.org/10.29264/jkin. v16i2.6060

Ternyata Masih Ada Kembalian Uang Belanja dengan Permen. (2018). https://www.kompasiana.com/

Zainudin, A. (2016). Metode Penelitian Hukum. Sinar Grafika. 